\title{
Bedømmelse og censur
}

\author{
Lotte Rienecker, (centerleder ved Akademisk Skrivecenter, Kobenhavns Universitet) og Rie Troel- \\ sen (adjunkt i naturfagsdidaktik, Danmarks Pcedagogiske Universitet), redaktorer af Dansk Uni- \\ versitetspedagogisk Tidsskrift nr. 1.
}

Bedømmelse og censur af opgaver og specialer på universiteterne er til debat og under forandring. Karakterskalaen er foreslået ændret gennem et større kommissionsarbejde, mange undervisere og studienævn ønsker andre kvalifikationer og kompetencer bedømt end de gammelkendte, og censorinstitutionens opgave og funktion er ikke længere givet i dens nuværende form. I dette første nummer af Dansk Universitetspædagogisk Tidsskrift fokuserer alle bidrag på bedømmelsernes forudsætninger, bedømmelseskriterier og eksamensformer, eksameners validitet og reliabilitet og på samarbejdet mellem lærer og censor og deres mediering af kriterier under censur. Bidragydere til dette nummer er universitetslærere og universitetspædagoger fra de pædagogiske centre, samt en censorformand (fra Psykologi).

Et genkommende og grundlæggende tema er hvorvidt og hvordan karaktergivning sker ud fra bedømmernes tavse viden eller om kriterierne fuldt ud kan ekspliciteres, verbaliseres, nedskrives, forhandles og offentliggøres. Nina Bonderup Dohn skriver om såvel de tavse og implicitte dimensioner af faglige bedømmelser, som om mulighederne for forhandling ud fra eksplicitte kriterier og om den udvikling, bedømmere gennemløber i deres forståelse af fagligt niveau.

Bedømmelser skal frem for alt være retfærdige, skriver Elsa Schmidt, og retfærdig og administrerbar bedømmelse er også målet for Anne Lindebo Holms arbejde med valide og reliable eksamensformer. En del af retfærdigheden sikres ved ekspliciterbare kriterier. Bedømmelser skal kunne kommunikeres til de studerende, men også til censorer, og nogle af disse kommer fra andre uddannelsessammenhænge end lærer/vejleder. I Signe Skovs arbejde med at eksplicitere hvad man som bedømmer - og vejleder - kan reagere på med hensyn til studerendes "stave- og formuleringsevne", ligger en bestræbelse på at differentiere de kriterier, man som bedømmer kan lægge ind i denne brede, officielle formulering. Signe Skovs artikel viser hvordan ekspliciterbare kriterier for at "trække ned» for dårligt sprog i opgaver kan være basis for undervisning og instruktion - inden bedømmelsen.

Den foreslåede nye karakterskala kan blive en anledning til ny eksplicitering, at sætte (nye) ord på kvalitetskriterierne bag tallene. Men det foreliggende forslag til ny karakterskala har faktisk ikke medtaget bemærkninger til skalaen, udover ganske korte sætninger som "Ingen eller fă uvæsentlige mangler" (for $A=12$ ) og dermed er dette forslag mindre verbaliseret end den foregående karakterskala. Hvis ordene ikke sættes på fra centralt hold, må de i endnu højere grad sættes på lokalt. Og noget tyder på at andre ord, andre kriterier for studiepræstationer end den gamle karakterbekendtgørelses ord om de ønskede kognitive operationer ("sammenligner, begrunder, analyserer" osv.), nu i nogle sammenhænge bliver nødvendige for at ramme den ønskede samlede præstation ind. Bedømmelse af proces i tilgift til produkt, sociale kompetencer i tilgift til kognitive er noget nyt, og det beskriver Jens Ejbye Schmidt og Mads Hermansen her eksempler på. Det er noget andet og mere, man gerne vil teste: Man søger efter bedømmelsesgrundlag der kan fange kompetencer som samarbejdsevner, deltagelse i gruppens arbejde, refleksion, proceshåndtering. Men det er ikke det, bemærkningerne i karakterskalaen er skrevet med henblik på. Måske er der brug for at få skrevet nogle nye der favner bredere. De sociale kompetencer er svært målbare, og synes at indbyde til bedømmelse i grovkategorien bestået/ikke bestået.

Men én pointe er at der er brug for ekspliciterbare og kommunikerbare kriterier for bedømmelser - de studerende har krav på at vide hvad de bliver bedømt på - en anden pointe er at med den kompetencebaserede undervisnings fokus på proces, kommer bedømmelser af de studerende mere og mere til at indgå som et styringsredskab for den fortløbende undervisning og ikke alene som en afsluttende vurdering, som Simon Olling Rebsdorf i sin artikel kommer ind på. Er vi med mappeevalueringer og procesbedømmelser på vej mod årskarakterer i universitetsundervisning?

Den censorinstitution hvis fremtid nu er til diskus- 
sion, har hidtil haft en rolle som sikring mod lærer/underviser som eneste administrator af kriterier for den gode præstation. Censorinstitutionens (uanset om den i fremtiden bemandes med erhvervslivets repræsentanter) mulige udviklingspotentiale ligger netop $i$ at her kan ekspliciteringer, eksemplificeringer, verbaliseringer og forhandlinger foregå. Der er brug for en fortløbende diskussion og legitimering af de kriterier der bedømmes og censureres ud fra. Kriterierne skal være sammenhængende med hvordan studieordningerne skrives, og progressionen i studiernes curriculum sikres. 